\title{
ASSESSING ALTERNATIVES TO ESTIMATE THE STEM VOLUME OF A SEASONAL SEMI-DECIDUOUS FOREST
}

\author{
Jadson Coelho de Abreu ${ }^{1 *}$, Carlos Pedro Boechat Soares ${ }^{2}$, Helio Garcia Leite ${ }^{2}$ \\ ${ }^{1}$ State University of Amapá, College of Forestry, Macapá, Amapa, Brazil - jadson.abreu@ueap.edu.br \\ ${ }^{2}$ Federal University of Viçosa, Department of Forestry, Viçosa, Minas Gerais, Brazil - csoares@ufv.br, hgleite@gmail.com
}

Received for publication: 02/08/2017 - Accepted for publication: 30/10/2017

\begin{abstract}
The objective of this study was to evaluate the use of linear and hybrid linear models, artificial neural networks (ANN) and support vector machine (SVM) in the estimation of the stem volume in a Seasonal Semi-deciduous Forest. Cubing data of 99 sample-trees of 15 species were used for this purpose. After analysis, we verified that the inclusion of the species as random effect did not contribute to increase the accuracy of the estimates in the structure of a hybrid model. Artificial neural networks and support vector machines, including species as input categorical variables, were the best alternatives to estimate the stem volume of trees of the Seasonal Semi-deciduous Forest.

Keywords: Stem volume; artificial neural networks; support vector machines; hybrid linear models; unevenaged forest.
\end{abstract}

\section{Resumo}

Avaliando alternativas para estimar o volume do fuste de uma Floresta Estacional Semidecidual. O objetivo desse estudo foi avaliar o uso de modelos lineares e lineares mistos, redes neurais artificiais (RNA) e máquina de vetor de suporte (MVS) na estimação dos volumes dos fustes de árvores em uma Floresta Estacional Semidecidual. Dados de cubagem de 99 árvores-amostra de 15 espécies foram utilizados para esta finalidade. Após análises, verificou-se que a inclusão das espécies como efeito aleatório não contribuiu para aumentar a exatidão das estimativas na estrutura de um modelo misto. As redes neurais artificiais e as máquinas de vetores de suporte, incluindo as espécies como variáveis categóricas de entrada, foram as melhores alternativas para estimar o volume dos fustes das árvores da Floresta Estacional Semidecidual.

Palavras-chave: Volume do fuste; redes neurais artificiais; máquinas de vetor de suporte; modelos lineares mistos; floresta inequiânea.

\section{INTRODUCTION}

The estimation of the volume of individual trees is essential to quantify wood stocks in forest stands. The use of volume equations is common (SOARES et al., 2011; CAMPOS and LEITE, 2017). In Brazil, numerous works have been developed and published on this subject. These works were reported in a compendium of volume and tapering equations for forest species in different geographic regions of Brazil by Figueiredo Filho et al. (2014).

In the specific case of uneven-aged forests, volumetric equations are not always available for all species. Normally, data collected from the most abundant species of the forest are used to represent the tree dimensions and to adjust a single equation that estimates the volumes of all species (AMARO, 2010). This procedure is most often justified by the large number of species that form forests with a low number of individuals concentrated in few diameter classes, which complicates the adjustment of volume equations by species.

Considering that there are different alternatives that may be used to estimate the volume of trees in even-aged stands, in contrast to classical regression models, such as hybrid models (GOUVEIA et al., 2015), artificial neural networks (BINOTI et al., 2014; GÖRGENS et al., 2014) and support vector machine (BINOTI et al., 2016), we verified the possibility of using these approaches on the estimation of volumes for the different species that form the uneven-aged forest. For this purpose, in addition to the input (or explanatory) variables, such as tree diameter and height, the species can also be included as random effects in a hybrid structure model by including random intercepts and inclinations, or as categorical variables in the artificial neural networks (ANN), and support vector machines (SVM).

Therefore, this work was conducted with the objective of assessing the use of linear and hybrid linear models, ANN and SVM in the estimation of tree volumes of species in a Seasonal Semi-deciduous Forest. 


\section{MATERIAL AND METHODS}

This study was conducted with data from a fragment of Seasonal Semi-deciduous Forest, located in the municipality of Viçosa-MG (VELOSO et al., 1991). The local climate according to Köppen classification is $\mathrm{Cwb}$, warm temperate, with maximum average temperature of $26{ }^{\circ} \mathrm{C}$ and minimum average of $14{ }^{\circ} \mathrm{C}$, hot and rainy summers and cold and dry winters. The average annual precipitation is approximately $1,338 \mathrm{~mm}$ (OLIVEIRA JUNIOR and DIAS, 2005).

Based on the parameters of the horizontal structure of the phytosociological analysis after forest inventory, 15 tree species and 99 sample-trees were selected for the determination of the volume (Table 1), using the Smalian formula.

Table 1. Distribution of the number of sample-trees selected by diameter class and by species.

Tabela 1. Distribuição do número de árvores-amostra selecionadas por classe de diâmetro e por espécie.

\begin{tabular}{|c|c|c|c|c|c|c|c|c|c|c|c|c|c|c|c|c|}
\hline \multirow[b]{2}{*}{ Espécie } & \multirow[b]{2}{*}{7,5} & \multirow[b]{2}{*}{12,5} & \multirow[b]{2}{*}{17,5} & \multirow[b]{2}{*}{22,5} & \multicolumn{6}{|c|}{ Centro de classe de diâmetro $(\mathrm{cm})$} & \multirow[b]{2}{*}{$\mathbf{5 7 , 5}$} & \multirow[b]{2}{*}{62,5} & \multirow[b]{2}{*}{67,5} & \multirow[b]{2}{*}{72,5} & \multirow[b]{2}{*}{$\mathbf{7 7 , 5}$} & \multirow[b]{2}{*}{ Total } \\
\hline & & & & & 27,5 & 32,5 & 37,5 & 42,5 & 47,5 & 52,5 & & & & & & \\
\hline Allophylus edulis & 1 & 1 & 1 & 1 & 1 & 1 & & & & & & & & & & 6 \\
\hline Anadenanthera macrocarpa & 1 & 1 & 1 & 1 & 1 & 2 & 5 & 3 & 3 & 1 & 1 & 2 & 1 & 1 & & 24 \\
\hline Anadenanthera peregrina & & & & 1 & & & & 1 & & 2 & 1 & & 1 & & & 6 \\
\hline Apuleia leiocarpa & 1 & 1 & 1 & 1 & 1 & 1 & 2 & 1 & & & & & & & & 9 \\
\hline Cariniana estrellensis & & & & & & & & & & 1 & & & & & & 1 \\
\hline Casearia ulmifolia & 1 & 1 & 1 & 1 & & 3 & & 1 & & & & & & & & 8 \\
\hline Copaifera langsdorffii & 1 & 1 & 1 & & 1 & & & & 1 & & & & & & & 5 \\
\hline Maprounea guianensis & & & 1 & & 1 & 2 & 1 & & & & & & & & & 5 \\
\hline Newtonia contorta & 1 & 1 & 1 & 1 & 2 & & 1 & & 3 & 1 & & & & 1 & 1 & 13 \\
\hline Ocotea pretiosa & 1 & & 1 & 1 & & & & & & 1 & & & & & & 4 \\
\hline Piptadenia gonoacantha & & & & & & & & 2 & & & & & & & & 2 \\
\hline Platypodium elegans & 1 & 1 & & 1 & 1 & & & & 2 & & & & & & & 6 \\
\hline Siparuna guianensis & 1 & & & & & & & & & 1 & & & & & & 2 \\
\hline Tapirira guianensis & & 1 & 2 & 1 & 1 & & & 1 & & 1 & & & & & & 7 \\
\hline Trattinickia rhoifolia & & & & & & & & & & 1 & & & & & & 1 \\
\hline Total & 9 & 8 & 10 & 9 & 9 & 9 & 9 & 9 & 9 & 9 & 2 & 2 & 2 & 2 & 1 & 99 \\
\hline
\end{tabular}

All the selected sample-trees had their diameters with bark at breast height $(d b h)$ and stems heights $(H)$ measured by diameter tape and Vertex IV hypsometer, respectively. The volumes of stem with bark were obtained by the successive application of the Smalian expression (HUSCH et al., 2003), and the diameters with bark at the base of the stem $(0 \mathrm{~m})$, at $1.3 \mathrm{~m}$, and then in sections of 2.0 in $2.0 \mathrm{~m}$ until the top of the treetop were measured. The diameters along the stem were estimated by using the Wheeler pentaprism (MACHADO; FIGUEIREDO FILHO, 2003) and the heights of occurrence of the diameters, by using a telescopic ruler.

\section{Adjustments of equation}

With the data of volume with bark, stem diameter and height, an equation regarding the model of Schumacher and Hall (1933) in its linear form was initially set. The equation is given by:

$$
\operatorname{LnV}=\beta_{0}+\beta_{1} \operatorname{Lndap}+\beta_{2} \operatorname{Ln} H+\varepsilon
$$

In which: $L n=$ natural logarithm; $V=$ commercial volume with bark, in $\mathrm{m}^{3} ; d b h=$ diameter with bark at breast height, in $\mathrm{cm} ; H=$ commercial height of the stem, in $\mathrm{m} ; \beta_{0}$ to $\beta_{2}=$ model parameters; $\varepsilon=$ random error.

The adjustment of the previous equation was executed by using the Maximum Likelihood Method, through the R software package glm2(R DEVELOPMENT CORE TEAM, 2014). The adjustment assessment was performed by using the correlation coefficient $\left(\mathrm{r}_{\mathrm{y} \widehat{\mathrm{y}}}\right)$ between the observed and estimated volumes (SILVA et al., 2009; and BINOTI, 2010).

Later, the model of Schumacher and Hall (1933) was adjusted, considering the structure of a hybrid linear model, by the inclusion of random intercept and inclination coefficients. Species with random effect were also considered, resulting in the following model:

$$
\operatorname{LnV}=\left(\beta_{0}+a_{i}\right)+\left(\beta_{1}+b_{1 i}\right) \cdot \operatorname{Lndap}+\left(\beta_{2}+b_{2 i}\right) \cdot \operatorname{Ln} H+\varepsilon
$$


In which: $\beta_{0}, \beta_{1}$ and $\beta_{2}=$ fixed parameters of the model; $a_{i}=$ random intercept for the ith species; $b_{1 i} a b_{2 i}=$ random inclination coefficients for the $i$ th species.

The adjustment of the equations related to the hybrid model was executed by the Maximum Likelihood Method, using the R software package nlme (R DEVELOPMENT CORE TEAM, 2014).

The result of the inclusion of the random effect on intercept and inclinations was verified by means of the Maximum Likelihood Ratio Test (RESENDE et al., 2014), in which the significance of the difference (D) between the deviances $(-2 \log (\mathrm{L}))$ for the models with and without the random effect was verified by comparing the calculated value with the value tabulated by the $\chi^{2}$ test with one degree of freedom and $5 \%$ of significance.

Thus, at the end of this modeling process, the model selected as the best hybrid linear model was the complete model or the partial model, i.e., with random effect associated with only a few model parameters, or even, the fixed effect model, due to the non-significance of the random effect.

\section{Neural networks and support vector machine}

A total of 100 neural networks of Multilayer Perceptron (MLP) type and ADALINE type (with no hidden layer) out of $100 \%$ data were trained in a controlled way, using the (Backpropagation) and (Simulated Annealing) training algorithms, respectively. Initially, the $d b h$ and stem height $(H)$ were adopted as input variables and the volume as output variable. Subsequently, the species as well as the diameter and height were included as input variable (categorical) in order to verify the effect of this variable on the accuracy of the volume estimates generated by the networks. The adopted training stop criteria for the ANN were: mean square error (0.001) and number of cycles (1000).

For the SVM training, eight configurations formed from two error functions and four Kernel functions were used. The optimized error functions were: type I function and type II function, given by:

\section{Type I function}

$$
\operatorname{Minimizar} \frac{1}{2} \cdot w^{T} w+C \cdot \sum_{i=1}^{N} \xi_{i}+C \cdot \sum_{i=1}^{N} \xi_{i}^{*}
$$

Subject to the following restrictions:

$$
\begin{aligned}
& w^{T} . \phi \cdot\left(x_{i}\right)+b-y_{i} \leq \varepsilon+\xi_{i}^{*} \\
& y_{i}-w^{T} . \phi \cdot\left(x_{i}\right)-b \leq \varepsilon+\xi_{i} \\
& \xi_{i}, \xi_{i}^{*} \geq 0, i=1, \ldots, N
\end{aligned}
$$

In which: $w=$ - coefficients vector; $C=$ error penalty parameter; $\xi, \xi^{*}=$ slack variables that characterize, respectively, error above and below the $\varepsilon$-tube; $i=$ training cases; $N=$ total number of training cases; $\phi .\left(x_{i}\right)=$ Kernel used; $b=$ bias; $y_{i}=$ output data and $\varepsilon=$ the maximum admitted error.

\section{Type II function}

$$
\operatorname{Minimizar} \frac{1}{2} \cdot w^{T} w-C\left(v \cdot \varepsilon+\frac{1}{N} \cdot \sum_{i=1}^{N}\left(\xi_{i}+\xi_{i}^{*}\right)\right)
$$

Subject to the following restrictions:

$$
\begin{gathered}
\left(w^{T} . \phi \cdot\left(x_{i}\right)+b\right)-y_{i} \leq \varepsilon+\xi_{i} \\
y_{i}-\left(w^{T} \cdot \phi \cdot\left(x_{i}\right)+b\right) \leq \varepsilon+\xi_{i}^{*} \\
\xi_{i}, \xi_{i}^{*} \geq 0, i=1, \ldots, N, \varepsilon \geq 0
\end{gathered}
$$


In which: $v=$ parameter that regulates the number of support vectors.

The Kernel functions assessed were: linear, polynomial, radial basis function (RBF) and sigmoid (Table 2).

Table 2. Kernel functions tested on support vector machines.

Tabela 2. Funções de Kernel testadas nas máquinas de vetores de suporte.

\begin{tabular}{ccc}
\hline Kernel Type & Function & Parameters \\
\hline Linear & $K\left(X_{i} \cdot X_{j}\right)$ & $\gamma, d, C$ \\
Polynomial & $K\left(X_{i} \cdot X_{j}\right)=\left(\gamma \cdot X_{i} \cdot X_{j}+C\right)^{d}$ & $\gamma$ \\
RBF & $K\left(X_{i} \cdot X_{j}\right)=e^{\left.\underline{\left(-\gamma\left|X_{i}-X_{j}\right|^{2}\right.}\right)}$ & $\gamma, C$ \\
Sigmoidal & $K\left(X_{i} \cdot X_{j}\right)=\tanh \left(\gamma \cdot X_{i} \cdot X_{j}+C\right)$ & \\
\hline
\end{tabular}

In which: $K\left(X_{i} . X_{j}\right)=\left\langle\phi\left(X_{i}\right), \phi\left(X_{j}\right)\right\rangle$ e represents the Kernel function applied to the input data; $\gamma=$ shape parameter; $d=$ degree of the polynomial; $C=$ penalty error parameter.

For the adjustment of the eight SVM configurations, the diameter $(d b h)$ and stem heights $(\mathrm{H})$ were initially considered as input variables, and the stem volume (V) as output variable. Later, the species was included as an input variable to verify its effect on the adjustment of the SVM.

Due to the low number of observations for some species and the need to compare the methods assessed in the same database, the validation process was not conducted for the ANN and SVM. All the adjustments of the neural networks and support vector machines were performed in Statistica software, version 12.0 (STATSOFT, 2013) and NeuroForest 4.06 (NeuroForest, 2017).

\section{Comparison of assessed alternatives.}

In order to enable the comparison of the equation adjustments for the linear model of hybrid effect and fixed effect with the ANN and SVM, the following assessment criteria, calculated in the original unit of the dependent variable $\left(\mathrm{m}^{3}\right)$, were used: correlation coefficient $\left(\mathrm{r}_{\mathrm{y} \widehat{\mathrm{y}}}\right)$ between the observed and estimated volumes, root mean square error (RMSE), bias, mean absolute differences (MDA) and graphical analysis of the residues (SILVA et al., 2009; BINOTI, 2010).

\section{RESULTS}

The equation for the model of Schumacher and Hall (1933) was adjusted to the observed stem volume data, and the parameters estimates were all statistically significant $(\mathrm{p}<0.01)$ (Table 3$)$.

Table 3. Estimates of the parameters of the model of Schumacher and Hall (1933), significance level and measurement accuracy and precision.

Tabela 3. Estimativas dos parâmetros do modelo de Schumacher e Hall (1933), nível de significância e medidas de precisão e de exatidão.

\begin{tabular}{lcccccc}
\hline Parameters & Estimates & p-value & $\mathrm{r}_{\mathrm{y} \widehat{y}}$ & RMSE\% & MAD & BIAS \\
\hline$\beta_{0}$ & -9.19591 & $<0.01$ & 0.9838 & 21.23 & 0.1067 & -0.0029 \\
$\beta_{1}$ & 2.03989 & $<0.01$ & & & & \\
$\beta_{2}$ & 0.72352 & $<0.01$ & & & & \\
\hline
\end{tabular}

By using the Maximum Likelihood Ratio Test, it was verified that the inclusion of the species as a random effect was not significant $(\mathrm{p}>0.05)$ in the model $(\mathrm{AIC}=118.41)$. Thus, the final model resulted in a model with only fixed effects (diameter and height) $(\mathrm{AIC}=124.41)$.

Neural networks demonstrated very good performance in the estimation of the stem volumes of the trees. MLP networks performed slightly better than the networks belonging to the Adaline type (Table 4). The SVM selected with best results were those with error function of type II with radial basis function Kernel (RBF). 
It should be noted that the inclusion of the species as an input categorical variable in the networks and vector machines (ANN MLP-17-14-1-S; ANN Adaline 17-1-S; SVM Type II-RBF-S) resulted in greater precision of the estimates.

Table 4. Statistics of the best artificial neural networks (ANN), and support vector machines (SVM) derived from the supervised training.

Tabela 4. Estatísticas das melhores redes neurais artificiais (RNA) e máquinas de vetores de suporte (MVS) resultantes do treinamento supervisionado.

\begin{tabular}{lllll}
\hline Alternatives & \multicolumn{1}{c}{$\mathrm{r}_{\mathrm{y} \widehat{\mathrm{y}}}$} & RMSE\% & MAD & BIAS \\
\hline ANN MLP-2-5-1-G & 0.9918 & 14.89 & 0.1140 & -0.0084 \\
ANN MLP-17-14-1-S & 0.9959 & 10.62 & 0.0713 & -0.0049 \\
ANN ADALINE 2-1-G & 0.9768 & 24.82 & 0.1639 & -0.0069 \\
ANN ADALINE 17-1-S & 0.9879 & 18.24 & 0.1285 & -0.0172 \\
SVM Type II-RBF-G & 0.9880 & 18.04 & 0.1116 & 0.0062 \\
SVM Type II-RBF-S & 0.9920 & 15.06 & 0.1020 & -0.0087 \\
\hline G = no species as a categorical variable; S $=$ species as an input categorical variable. &
\end{tabular}

$\mathrm{G}=$ no species as a categorical variable; $\mathrm{S}=$ species as an input categorical variable.

By analyzing the correlations between the observed and estimated volumes (Tables 3 and 4), and the graphics of the residuals (Figure 1), we observed that the ANN MLP-17-14-1-S and the SVM Type II RBF - S, which include the species as categorical variables, were the best alternatives for the estimation of the stem volumes of trees that are native to Seasonal Semi-deciduous Forest. ANN Adaline 2-1 with no species as input variable, was, in turn, the least accurate alternative.
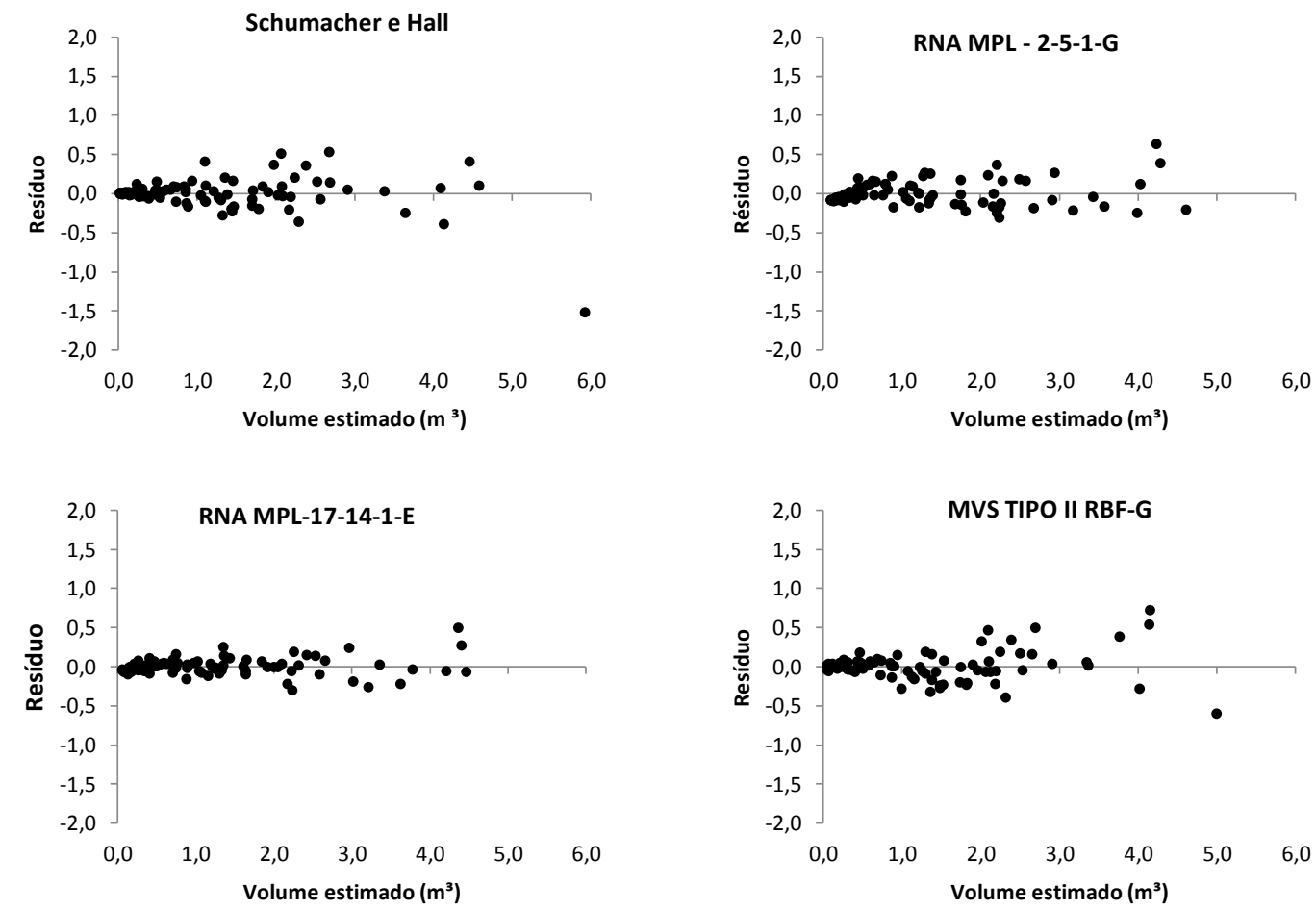

FLORESTA, Curitiba, PR, v. 47, n. 4, p. 375-382, out/dez. 2017

Abreu, J. C. et al.

ISSN eletrônico 1982-4688

DOI: $10.5380 /$ rf.v47i4.54259 

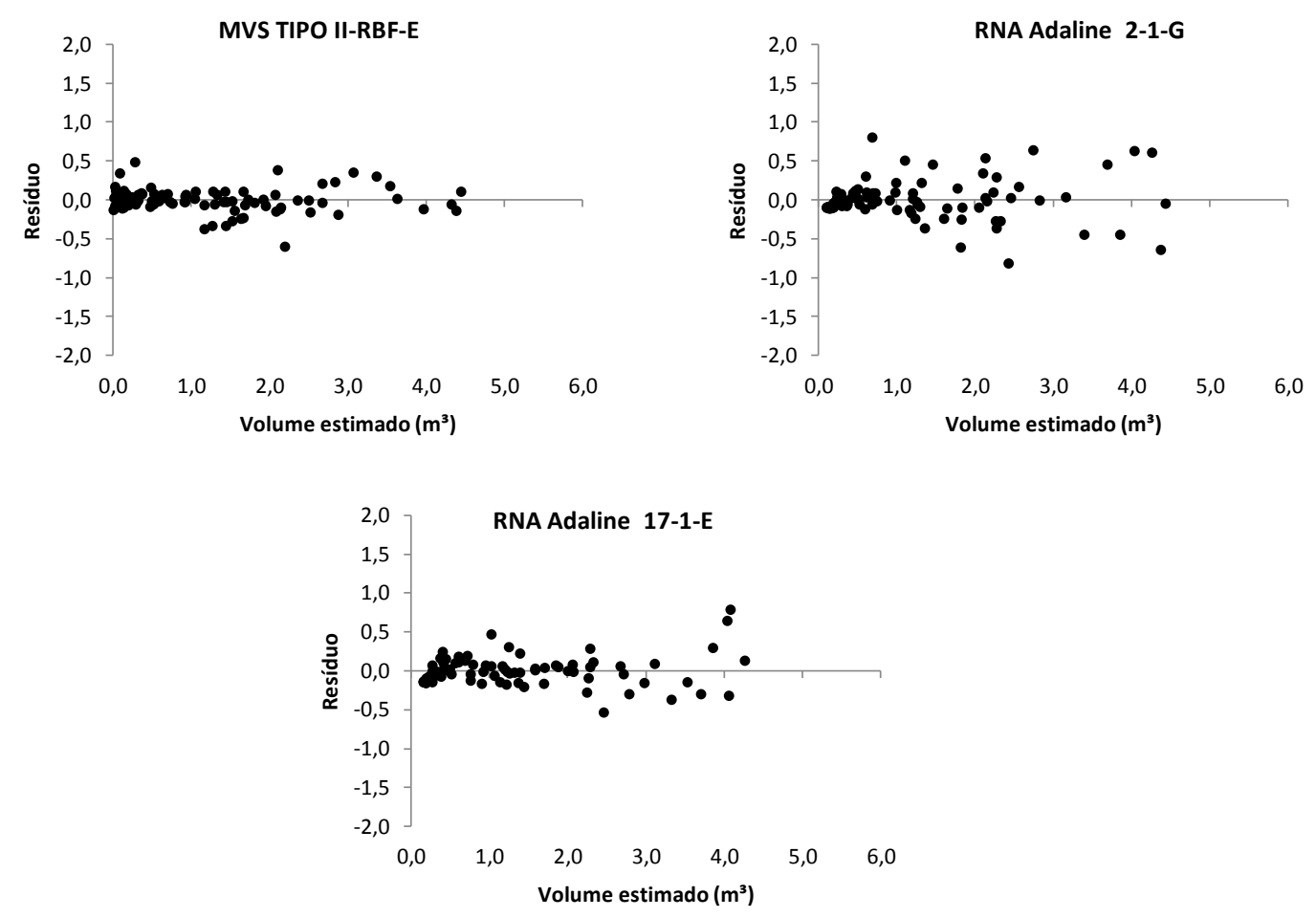

Figure 1. Graphic of residuals of the equation of Schumacher and Hall; artificial neural networks (RNA); support vector machine (MVS), including the species (E) or not (G) as categorical variables.

Figura 1. Gráfico de resíduos da equação de Schumacher e Hall; redes neurais artificias (RNA); máquina de vetor de suporte (MVS), incluindo as espécies (E) ou não $(\mathrm{G})$ como variáveis categóricas.

\section{DISCUSSION}

All the assessed alternatives estimated the volumes of stems of trees of the species sampled in the Seasonal Semi-deciduous Forest accurately. The equation of volume, even with the highest amplitude of data compared to data from plantations of commercial species, revealed to be precise and in accordance with the equations of other studies for the same typology (CETEC, 1995; FIGUEIREDO FILHO et al., 2014).

However, the volume equation from the model of Schumacher and Hall (1933) presented a residual with an estimate whose value was discrepant from the others (Figure 1). Since the regression line passes through the mean value of the observations (GUJARATI, 2011), a discrepant value in data distribution can result in this residuals behavior. This behavior was not observed in the ANN and in the SVM, i. e., the networks were able to estimate this discrepant volume datum accurately with no loss to other estimates, being an advantage of the networks and support vector machines on the volume equations.

When analyzing the contribution of the species to the adjustment of equations, we observed that three species (Anadenanthera macrocarpa, Apulei leiocarpa and Newtonia contorta) represent approximately $46.5 \%$ of the volume data, exerting a great influence upon the mean behavior of the adjusted curve. In this sense, data resulting from the volumes of other species were not sufficient to make the inclusion of species as a random effect in the hybrid model meaningful.

In this study, we considered the variances as homogeneous, since the transformation of the logarithmic data usually provides the answer to the assumption of the classical linear regression model and the covariances equal to zero, considering the non-use of longitudinal data (GUJARATI, 2011). However, structures of variances and covariances can be assessed (PINHEIROS; BATES, 2000) by identifying those that may provide better results in studies of this nature.

The artificial neural networks resulted in accurate estimates of the volumes of stems of trees that are native to the Seasonal Semi-deciduous Forest; fact also observed for even-aged stands by Binoti et al. (2014). We highlight the Adaline network, whose performance reached similar results when compared to the MLP network. The performance of the SVM was also very similar to that found in an application study of this 
computational intelligence technique in even-aged stand (BINOTI et al, 2016; MONTAÑO, 2016). It reveals that even with data with greater variability, the MVS can be used to estimate the stem volume of native species trees in typologies such as the Seasonal Semi-deciduous Forest.

When regression analysis is used in studies similar to this one, the validation of the equations is usually made with the adjustment data themselves (CHICORRO et al, 2003; SCOLFOTO et al., 2008; RUFINI et al., 2010). The equations are normally recommended in accordance with the validation done with the adjustment data. By the same reasoning, although we did not assess independent data, the trained network is robust and there is no risk of memorization with the proposed configuration. Accordingly, it can be used for generalization without risk of bias. Finally, to prove its efficiency, hypothetical and sequential input data were applied to the trained ANN 17-14-1-S, demonstrating the consistency between the input variables and the output of the network (FIGURE 2). Another important evidence in the case of figure 2 is the exponential relationship between the volumes estimated by the ANN and the dbh of trees, expected from the allometric perspective.

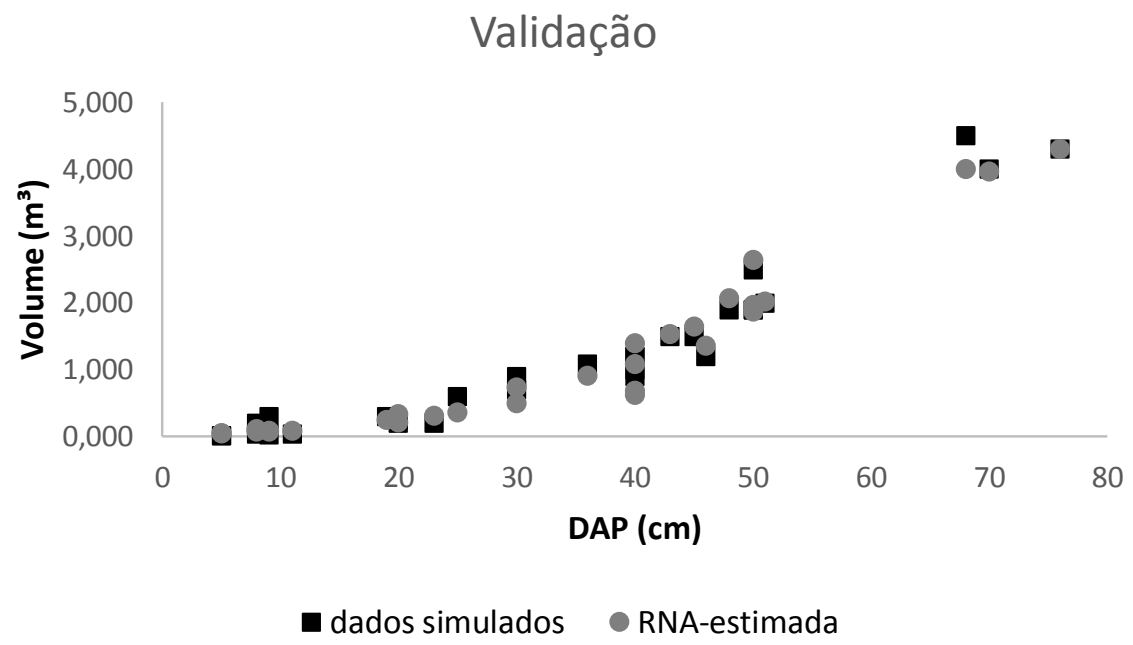

Figure 2. Graphic of the estimation of artificial neural network (RNA17-14-1), including the species (E) on simulated data.

Figura 2. Gráfico da estimativa da rede neural artificial (ANN 17-14-1), incluindo as espécies (E) sobre dados simulados.

\section{CONCLUSIONS}

- The artificial neural networks (ANN) and support vector machines (SVM), including the species as input categorical variables, seem to be better alternatives to estimate the stem volumes of trees that are native to the Seasonal Semi-deciduous Forest, regarding the use of the model of Schumacher and Hall. The inclusion of the species as a random effect in a hybrid model does not contribute to the accuracy of the estimates.

\section{REFERENCES}

AMARO, M. A. Estimativas do estoque de volume, biomassa e carbono para fustes de árvores, subbosques e serapilheira em uma Floresta Estacional Semi-decidual Montana em Viçosa, MG. 2010. 180 f. Tese (Doutorado em Ciência Florestal) - Universidade Federal de Viçosa, Viçosa, MG, 2010.

BINOTI, M. L. M. S. Redes neurais artificiais para prognose da produção de povoamentos não desbastados de eucalipto. Tese (Doutorado) - Curso de Ciência Florestal, Universidade Federal de Viçosa, 2010.

BINOTI, M. L. M. S.; BINOTI, D. H. B.; LEITE, H. G.; GARCIA, S. L. R.; FERREIRA, M. Z.; RODE, R.; SILVA, A. A. L. Redes neurais artificiais para estimação do volume de árvores. Revista Árvore, v. 38, p. 283288, 2014.

BINOTI, D. H. B.; BINOTI, M. L. M. S.; LEITE, H. G.; ANDRADE, A. V.; NOGUEIRA, G. S.; OLIVEIRA, M. L. R.; PITANGUI, C. G. Support vector machine to estimate the volume of eucalypt trees. Revista Árvore, v. 40, p. 689-693, 2016. 
CAMPOS, J. C. C.; LEITE, H. G. Mensuração Florestal: perguntas e respostas. 5.ed. atualizada e ampliada. Viçosa: Editora UFV. 2017. 636 p.

FUNDAÇÃO CENTRO TECNOLÓGICO DE MINAS GERAIS (CETEC) Determinação de equações volumétricas aplicáveis ao manejo sustentado de florestas nativas no estado de Minas Gerais e outras regiões do país. Convênio: FAPEMIG/ CETEC. Belo Horizonte, Brazil. 1995. 295 p.

CHICORRO, J. F.; RESENDE, J. L. P.; LEITE, H. G. Equações de volume e de taper para quantificar multiprodutos da madeira em floresta atlântica. Revista Árvore, Viçosa-MG, v. 27, n. 6, p. 799-809, 2003.

FIGUEIREDO FILHO, A.; MACHADO, S. A.; MIRANDA, A. O. V.; RETSLAFF, F. A. S. Compêndio de equações de volume e afilamento de espécies florestais plantadas e nativas para as regiões geográficas do Brasil. Curitiba, PR, Brazil: edited by the authors. 2014. 306 p.

GOUVEIA, J. F.; SILVA, J. A. A.; FERREIRA, R. L. C.; GADELHA, F. H. L.; LIMA FILHO, L. M. A. Modelos volumétricos mistos em clones de Eucalyptus no polo gesseiro do Araripe, Pernambuco. Floresta, v. 45, p. 587-598, 2015.

GÖRGENS, E. B.; LEITE, H. G.; GLERIANI, J. M.; SOARES, C. P. B.; CEOLIN, A. Influência da arquitetura na estimativa de volume de árvores individuais por meio de redes neurais artificiais. Revista Árvore, v. 38, p. 289-295, 2014.

GUJARATI, D. N.; PORTER, D. C. Econometria básica. 5 ed. Porto Alegre: AMGH Editora, 2011. 920 p.

MACHADO, S. A.; FIGUEIREDO FILHO, A. Dendrometria. Curitiba-PR/Brazil: UFPR, 2003. 309 p.

MONTAÑO, R. A. N. R. Aplicação de técnicas de aprendizagem de máquinas na mensuração florestal. 2016. 86f. Tese (Doutorado em Informática) - Universidade Federal do Paraná, Curitiba-PR, 2016.

NEUROFOREST. Available at: 〈http://neuroforest.ucoz.com/>. Accessed on: 07 July. 2017.

OLIVEIRA JUNIOR, J. C.; DIAS, H. C. T. Precipitação efetiva em fragmento secundário da Mata Atlântica. Revista Árvore, v. 29, n. 1, p. 9-15, 2005.

PINHEIRO, J. C.; BATES, D. M. The Mixed-efects models in S and S-PLUS. New York: Springer-Verlag, 2000. v. 1.528 p.

R CORE TEAM. R: A language and environment for statistical computing. R Foundation for Statistical Computing, Vienna, Austria. 2014. URL http://www.R-project.org/

RESENDE, M. D. V.; SILVA, F. F.; AZEVEDO, C. F. Estatística matemática, biométrica e computacional: Modelos mistos, multivariados, categóricos e generalizados (REML/BLUP), inferência bayesiana, regressão aleatória, seleção genômica, QTL-GWAS, estatística espacial e temporal, competição, sobrevivência. Viçosa: Suprema gráfica e Editora Ltda, 2014. 882 p.

RUFINI, A. L.; SCOLFORO, J. R. S.; OLIVEIRA, A. D.; MELLO, J. M. Equações volumétricas para o cerrado sensu stricto, em Minas Gerais. Revista Cerne, v. 16, n. 1, pp. 1-11. 2010.

SCHUMACHER, F. X.; HALL, F. D. S. Logarithmic expression of timber-tree volume. Journal of Agriculture Research, v. 47, n. 9, p. 719-734, 1933.

SCOLFORO, J. R. S.; RUFINI, A. L.; MELLO, J. M.; OLIVEIRA, A. D.; SILVA, C. P. C. Equações para estimar o volume de madeira das fisionomias, em Minas Gerais. ln: SCOLFORO, J. R. S; OLIVEIRA, A. D; ACERBI JUNIOR, F. W. (Org.). Inventário Floresta de Minas Gerais. Belo Horizonte, MG, Brazil. p. 67-114. 2008.

SILVA, M. L. M.; BINOTI, D. H. B.; GLERIANI, J. M.; LEITE, H. G. Ajuste do modelo de Schumacher e Hall e aplicação de redes neurais artificiais para estimar volume de árvores de eucalipto. Revista Árvore, v. 33, n. 6, p. 1133-1139, 2009.

STATSOFT, Inc. Statistica for Windows (data analysis software system), version 12. Statsoft, Tulsa, Oklahoma (USA), 2013.

VELOSO, H. P.; RANGEL FILHO, A. L. R.; LIMA, J. C. A. Classificação da vegetação brasileira adaptada a um sistema universal. São Paulo: IBGE, 1991. 123 p. 